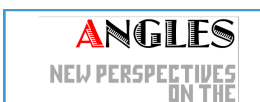
ANELOPHONE WORLD

\section{Angles}

New Perspectives on the Anglophone World

3 | 2016

Angles and limes

\title{
Angles and "limes" in American Studies: Ecofeminism in the research field
}

\section{Margot Lauwers}

\section{Q OpenEdition}

1 Journals

\section{Electronic version}

URL: https://journals.openedition.org/angles/1649

DOI: 10.4000/angles. 1649

ISSN: 2274-2042

\section{Publisher}

Société des Anglicistes de l'Enseignement Supérieur

\section{Electronic reference}

Margot Lauwers, "Angles and "limes" in American Studies: Ecofeminism in the research field", Angles [Online], 3 | 2016, Online since 01 November 2016, connection on 07 June 2022. URL: http:// journals.openedition.org/angles/1649; DOI: https://doi.org/10.4000/angles.1649

This text was automatically generated on 7 June 2022.

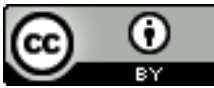

Angles est mise à disposition selon les termes de la Licence Creative Commons Attribution 4.0 International. 


\title{
Angles and "limes" in American Studies: Ecofeminism in the research field
}

\author{
Margot Lauwers
}

\section{Introduction}

1 Ecofeminism emerged on a global scale during the second half of the 1970s from crosslinking research on social justice and environmental health. At that time, several groundbreaking texts shed light upon the commonalities of oppressive structures based upon gender, ethnicity, species and the environment, notably The Lay of the Land by Annette Kolodny and New Woman, New Earth: Sexist Ideologies and Human Liberation by Rosemary Radford-Ruether, both published in 1975. These books were followed three years later by Susan Griffin's Woman and Nature: The Roaring Inside Her, and Mary Daly's Gyn/Ecology: The Metaethics of Radical Feminism. Then, in 1980, Carolyn Merchant published The Death of Nature: Women, Ecology and the Scientific Revolution. ${ }^{1}$

2 The ideas put forward by Mary Daly are often classified as pertaining to the radical side of feminism, despite the fact that she established a clear link between feminist thought and environmentalism. In her title, Daly already laid bare a liminal reflection on the concepts of women and ecology. By recalling the persecutions women suffered from in various historical eras and cultural areas-such as chinese foot-binding, genital mutilation in Africa or witch-hunting in Europe-she underscores the existence of a link between environmental and feminine health problems. Daly also calls attention to another issue: language, a topic she deems far more insidious and difficult to expose because it is all too often put aside as being a fruitless contention. Daly exhibits what she considers to be the three facets of a single problem: the male-dominated medicalization of women's bodies, the need to reconceptualize our relationships to women as well as to the environment, and the imperfection of language to which Daly opposes the necessity of a gyno-centered orientation of language and of thought. 
The same year, in a somewhat similar spirit, Susan Griffin published Woman and Nature: The Roaring Inside Her. In a manner reminiscent of Daly, Griffin broke with the traditional academic style and produced an impassioned prose poem in which she exposes the hypocrisy of Western industrial thinking as regards women and the environment. Throughout the book, the author paraphrases and weaves into her own writing texts from very different origins such as gynecological treatises, forestry handbooks, poems and scientific essays. The result is a powerful denunciation of the idea-present from the beginning of Western Antiquity-that women are, supposedly, closer to nature and, as a consequence, are bound to be, like nature itself, subjected to male domination.

Like Daly, Griffin tackles patriarchal structures head-on. She deconstructs patriarchy's voice from the inside, demonstrating how it can be full of prevarications, prejudice and metaphysical dishonesty. Here too, the author attacks language, which she considers as the pillar of the patriarchal system. By exposing the incoherencies of patriarchal discourse and the presumptions it managed to create through language, Woman and Nature reveals the absurdity and the authoritarianism of the discursive association which helped subordinate everything that did not fit into the "white male" category. Within her work, Griffin blurs traditional dualistic categorization through a polyphonic method as well as through the very nature of the book itself: partly academic treatise, narrative, and poem. These characteristics are both the strength and the weakness of this work.

What happened with this book was similar to what happened with the ecofeminist movement as a whole. The fact that the book was not clearly classifiable as being either an essay, a novel or a poem-but rather all these at once-forced the reader into rethinking his or her relationship to reading and to his or her tools for critical analysis. Studying this book in a fragmented way by concentrating, for example, only on its poetical or its essayist side is possible, of course, but something is then missing. This text should be approached in a trans-generic way, and the same goes for the movement it comes from. This all-encompassing perspective hindered the book's entering academic circles: looked upon as not conventional enough, considered as too "radical" or, worse, as "essentialist"-because it dealt with the problem in the round-the book's history is highly representative of ecofeminism's pathway.

6 In a totally different but no less interdisciplinary style, Carolyn Merchant published The Death of Nature: Women, Ecology, and the Scientific Revolution in 1980. Its author is a History of Sciences and Ethics professor at the University of Berkeley in California. Merchant defined the Enlightenment as being the time when science undertook to fragment and dissect nature. She claimed this resulted in nature's conception as inert and empty, a simple vase ready to welcome human colonization, reminiscent of the feminine body often regarded as an empty vessel awaiting male semen to produce the miracle of life. By drawing from the cross-linking studies of social feminism and environmentalism, The Death of Nature allows for a complete historical panorama of the reason why the domination of women and the exploitation of nature have common roots within the scientific and economic rationalism that has existed since the Middle Ages.

7 Merchant's work, with its solid historical documentation, was then at the premises of what is now referred to as "material feminism". Although their ideas are basically analogical, it appears to be the form that Daly and Griffin gave to their works that has proven problematic. This is particularly true for Griffin's Woman and Nature, which is 
grounded in thorough historical research work, and a comprehensive analysis of historical data (her sources are often similar to Merchant's). Sadly, the fact that Griffin's writing was not representative of traditional essay writing undermined the effect of the data she used. Her writing exploited subjectivity, for a large part, by pushing the reader into feeling the injustice it discusses by imitating it within the writing style. This gave way to a poetic text of great potency, but it also quelled the understanding of the subject the author was addressing. The form of the book is as multiple and heterogeneous as the subjects tackled by ecofeminism, and some of the latter's branches might seem somehow cultish. However, the academic works provided by ecofeminist scholars from various fields, as well as fiction and non-fiction ecofeminist narratives, constitute a strong basis for a transdisciplinary ecofeminist research field, though the very question of transdisciplinarity is the real bone of contention.

\section{Not enough angles and too many "limes"?}

8 As Griffin's example showed, ecofeminism's transdisciplinarity has been deemed problematic from its very beginnings. Retrospectively, it appears that this misunderstanding did not come from the movement's illegitimacy or its insignificance but rather from its transdisciplinarity. In other words, the attack on ecofeminism's transdisciplinarity was part of a general attempt to disqualify the ecofeminist approach as a whole. For example, in June 1992, the editors of Signs, a journal, refused an article on ecofeminism with the following arguments: "ecofeminism seems to be concerned with everything in the world [...] [as a result] feminism itself seems almost to get erased in the process [,] when [ecofeminism] contains all peoples and all injustices, the fine tuning and differentiation lose out" (reproduced in Gaard 1993: 32-3). This example illustrates the fact that the variety of ecofeminism's approaches and applications represented a problem for traditional modes of thinking.

However, a couple of years later, ecofeminist theory began solidifying globally, especially in the United States. Several groundbreaking anthologies were published, the first of which was Reclaim the Earth, edited by Leonie Caldecott and Stephanie Leland in 1983. This first truly transdisciplinary volume allowed to grasp the astonishing diversity which constituted ecofeminism:

Caldecott and Leland's volume bridged the later division between theory and activism, offering poetry as well as scholarship, and work by a diversity of feminists, including Wangari Maathai (Kenya) on the Green Belt Movement, Rosalie Bertell (Canada) on nuclear power and health, Wilmette Brown (UK/US) on black ghetto ecology, Marta Zabaleta (Argentina) on the Mothers of the Plaza de Mayo, the Manushi Collective (India) on female infanticide, and Anita Anand (India) on the Chipko Andolan. (Estok et al. 2013: 29)

Although they have similar goals, theory and grassroots movements used to function in distinct manners until then. Reclaim the Earth was the first work to establish longlasting links between the two spheres of action: activism and theory. Two articles published in that same period demonstrate the "global trait" of the ecofeminist movement. In "Deeper than Deep Ecology: the Eco-Feminist Connection" (1984), Australian Ariel Salleh offers a broadening of the reflection of the Deep Ecology movement which she considers too human-centered. Her arguments outlined what a combined approach to environmentalism and feminism could bring to ecology as a 
whole as she explained that it would allow for a more ethical treatment of all living beings. In 1986, German sociologist Maria Mies published "Patriarchy and Accumulation on a World Scale" in which she enhanced the theory she had only applied to her studies of the living conditions of women in India. Six years earlier, Mies had published a book in which she denounced the difficulties met by Indian women in fighting the extremely active patriarchal spirit of the country (Mies 1980). This interest in applying ecofeminist analyses to the Indian country allowed for the collaboration of Mies with another well-known ecofeminist, Vandana Shiva.

11 Both representative of the geographical scattering of ecofeminist scholars, these articles also opened the way to two others which were crucial for the movement: "Ecofeminism: an overview and discussion of positions and arguments" (1986) by Val Plumwood, and "Feminism and Ecology: Making Connections" by Karen Warren. Both contributions concentrated on the necessity of understanding the links between feminism and ecology and started to establish a more coherent ecofeminist thinking. Thanks to these works, Karen Warren later developed her "logic of domination" (Warren 1990: 126-132), which Val Plumwood described as the "master model" theory (Plumwood 1993: 23). These ideas were central to ecofeminism for this is how the links that existed mainly within capitalist patriarchy between environmental degradation and oppression due to gender, ethnicity, social class or sexual orientation were made visible through an environmental and feminist analysis.

This analysis shed light on a double relationship between nature and women (or other beings considered as "Feminised Others"). First, in a larger part of the world, women seem to suffer harder from environmental degradation because of the sexual division of labor that imposes the role of caretaker on women. The fact that these women are in charge of finding firewood, bringing water to the home, scavenging or finding food, and so on, places them at the forefront of feeling the increasing constraints of environmental change (by having to walk further and further for wood and water for example). This analysis is confirmed by data collected and presented in Women and Environment in the Third World (1988), by Joan Davidson and Irene Dankelman and in Staying Alive: Women, Ecology and Development (1989) by Vandana Shiva.

The other link between women and nature is said to exist on a conceptual level. This connection was articulated in very diverging ways, which is why it is hard to explain as a whole. The heart of the problem allegedly resides in the hierarchical and binary mode of thinking of Western societies, or societies influenced by the West. These conceptual structures have an ascendancy on the way the world is perceived and organized. Binary structures create pairs in which one is always conceptually devalued compared to the other. What is more, the devalued other is almost always perceived as being closer to nature and more feminized than the other half of the pair (e.g. reason/emotion or civilized/wild for example). These binary structures appear to be justified, sometimes even natural, whereas, according to ecofeminists, a re-evaluation of our philosophical and conceptual perception allows for a better understanding of the way they have, in fact, been socially and culturally constructed and are mutually reinforcing.

By the 1990s, ecofeminism was no longer a field in its infancy but rather a critical theory that could be applied to various fields, be they philosophical, sociological or semantical. Under Murray Bookchin's influence, Janet Biehl and Ynestra King started to develop a "social ecofeminism", a notion very close to what is nowadays referred to as "bioregionalism". In 1989, Carolyn Merchant published Ecological Revolutions. Nature, 
Gender and Science in New England; Barba Noske, Humans and Other Animals: Beyond the Boundaries of Anthropology and Judith Plant, Healing the Wounds: The Promise of Ecofeminism. The first two retraced, in a classical essayist fashion, the evolutions of ecofeminist thought as well as the movement's desire to fight the binarism traditionally at stake in Western societies in order to make the interrelated patterns of domination visible. In doing so, these writings took forward what the works of people such as Merchant, Plumwood, Salleh, Radford-Ruether and Mies had started to do, by showing how enriching a vision conjointly focused on gender and the environment could be.

Anthologies published in 1989 and 1990 have confirmed the importance of some of its participants, whose work quickly became keystones within the ecofeminism movement: Shiva (1988), Kheel (1988), King (1989), Spretnak (1982), Starhawk (1979, 1982) or Radford Ruether (1983). Both works offered essays pertaining to the deconstruction of binary thinking as well as poems, academic papers, philosophical myths and so on. Other works continued reinforcing these ideas, such as The Dreaded Comparison by Marjorie Spiegel (1988), The Rape of the Wild by Andrée Collard and Joyce Contrucci (1989), in the footsteps of Kolodny's The Lay of the Land (1975). By focusing on the correlative structures of science and technology, of militarism and hunting, of slavery and domesticity, Collard and Contrucci report on the way language, monotheistic religions and patriarchal cultures legitimate a relationship to the world which is based, even constructed on, domination and conquest.

\section{A hindering 'all-encompassingness'}

16 The last decade of the $20^{\text {th }}$ century witnessed a regular flow of publications which both reinforced and weakened ecofeminism. The diversity of standpoints turned ecofeminism into an ideology that had to be broached as a whole, which was exactly what discouraged people initially interested in its ideas. The few people who had been advocating what has been termed as "cultural ecofeminism"2 discredited the entire movement by making it appear as an essentialist celebration of a biological/natural link between women and nature:

Focusing on the celebration of goddess spirituality and the critique of patriarchy advanced in cultural ecofeminism, poststructuralist and other third-wave feminisms portrayed all ecofeminisms as an exclusively essentialist equation of women with nature, discrediting ecofeminism's diversity of arguments and standpoints [...]. (Gaard 1992: 32)

17 However, a large number of writings continued what the works from the previous decade had begun, namely: condemning the association between women, femininity and nature, and exposing this as the result of a social construction. Academic works brought proof of the fact that these social constructions, like the society which they originate from, are contextually anchored and mobile, rather than ahistorical and fixed as cultural ecofeminists claim them to be. Taking a newly materialist standpoint, the work of thinkers such as Lori Gruen (1993), Donna Haraway (1991), and Irene Diamond (1994) analyzed the structuring of the conceptual connection between women and nature. As such, the ecofeminist theory of the 1990s went one step further not only by bringing to light the various links that existed between oppressive structures, but also by focusing its analysis on the very structure of oppression. 
18 All this research tended to point to the fact that there existed a single logic of domination applied in analogical ways to varied groups, identified according to the dualistic disjunctions upon which Euro-American patriarchal capitalistic thinking was based. This logic of domination was at the heart of colonialism, racism, sexism and of what is now referred to as "speciesism" or "naturism." ${ }^{3}$ since all these forms of oppression are bound by the conceptualization that underpins them, ecofeminists claim that issues such as feminism, environmentalism, anti-racism, etc. should all be fought for together:

Ecofeminists insist that the sort of logic of domination used to justify the domination of humans by gender, racial or ethnic, or class status is also used to justify the domination of nature. Because eliminating a logic of domination is part of a feminist critique-whether a critique of patriarchy, white supremacist culture, or imperialism-ecofeminists insist that naturism is properly viewed as an integral part of any feminist solidarity movement to end sexist oppression and the logic of domination that conceptually grounds it. [...] Because, ultimately, these connections between sexism and naturism are conceptual-embedded in an oppressive conceptual framework-the logic of traditional feminism leads to the embracing of ecological feminism. (Warren 1990: 130)

19 According to Karen Warren, this is one of the reasons that serve to justify the common fight of environmentalism and feminism in the form of ecofeminism. Another reason can also be found in the manner in which gender and nature have both been conceptualized within Western patriarchal society:

Just as conceptions of gender are socially constructed, so are conceptions of nature. of course, the claim that women and nature are social constructions does not require anyone to deny that there are actual humans and actual trees, rivers and plants. It simply implies that how women and nature are conceived [of] is a matter of historical and social reality. These conceptions vary cross-culturally and by historical time period. As a result, any discussion of the "oppression or domination of nature" involves reference to historically specific forms of social domination of non-human nature by humans, just as the discussion of the "domination of women" refers to historically specific forms of social domination of women by men. [...] [And] involves showing that within patriarchy the feminization of nature and the naturalization of women [within language and concepts] have been crucial to the historically successful subordinations of both. (Warren 1990: 131)

20 However, in spite of the apparent solid theoretical foundation of ecofeminist ideas, earnest antagonisms started appearing with charges of essentialism. Some authors were classified as "dangerous" because their work was deemed too universalizing or because it seemed to uphold the idea that there was a universal feminine nature or a biologically-determined femininity.

The precise points of controversy concerning the essentialist bent of ecofeminism have become so complex that rehearsing every detail of the controversy would divert us from the purpose of this paper. In an effort to keep at bay the essentialist allegations, a large number of feminist and ecofeminist scholars belittled ecofeminism in general. In "Ecofeminism Revisited: Rejecting Essentialism and Re-Placing Species in a Material Feminist Environmentalism," Greta Gaard offers an interesting synthesis of the various discussions on the supposed essentialism of some ecofeminist approaches of the 1990s. In another article, "Misunderstanding Ecofeminism," she explains how the repeated attacks ecofeminism has had to suffer stem, she argues, from a misunderstanding:

The refusal to take ecofeminism seriously within circles of standardized feminist discourse has taken two forms: first, ecofeminism is wrong; second, ecofeminism is 
not taken seriously because to do so would require rethinking the entire structure of feminism. Since these explanations are mutually exclusive, they cannot both be true. It is worth noting that simultaneously holding two conflicting beliefs as true is a kind of doublethink which characterizes oppressive systems, and serves to keep the underclass paralyzed by paradox. That establishment feminism is now using this strategy is testimony to the hegemonic status feminism has achieved-and therefore, a signal of caution for how much credibility it should have. [...] Ecofeminism is generally thought to be "wrong" because critics have portrayed the theory as premised on the woman/nature connection: [...] But this charge can only be made by simple misunderstanding, sheer ignorance, or willful misrepresentation [...] (Gaard 1992: 21)

By setting the charges of essentialism which ecofeminism suffered within the larger historical context of the feminist movements of the past fifty years, one notices that a similar debate was waged within feminist currents of thoughts from which ecofeminism originated. Among the many branches of feminism ${ }^{4}$ some currents are called 'differential' or 'cultural' as they predicate a biologically-determined nature (as opposed to the social constructionist standpoint put forth by other feminisms), and advocate a necessary recognition of a feminine life-experience.

Although more general feminist movements have endlessly disowned these ideas, they have to be taken into consideration when trying to historically contextualize feminist movements in general-be it just to acknowledge that they are but a small part of a much larger whole, and that they should by no means be substituted to it. It is important to bear in mind that the same is true for ideas held up by cultural ecofeminism which represents only a small part of a larger movement. In the same way that one cannot reject all forms of feminism on the pretext that some of its branches are differential or cultural, one cannot reject the whole of ecofeminist ideologies for the sole reason that some of its advocates base their premises on the "existence of a presupposed link" (Brugeron 2009: 1) between the "eco" and the "feminine" which binds together nature and women's biological characteristics.

Using specific characteristics of a distinctly cultural or spiritual branch of a movement in order to present these as being inherent qualities of the more general current of thought is a move that could itself be called essentialist, since it amounts to "misrepresenting the part for the whole" (Gaard 1992: 21). As such, it appears that most of the feminist movements which rejected ecofeminism in its entirety because of a conflation between a part and the whole actually applied the same patriarchal systems' thinking they have been trying to fight from the beginning.

This illustrates what the ecofeminist movement blames the feminist and environmentalist movements for: they reproduce the exact dualistic thought structure (and thus also the underlying logic of domination) that they are intending to fight in patriarchal and anthropocentric systems. This reproduction of the "value-hierarchical dualities," a term used by Warren (1993: 255), imitates the dichotomies rejected by most feminist movements such as body/mind, woman/man, emotion/reason, etc. and which ecofeminist scholars have extended to other dualistic structures such as nature/ culture, white/non-white, human/non-human, etc. If we follow Warren and Plumwood's theories, among others, according to which a classification in one category or the other prompts a conceptual coalescence of the various components of these dichotomies, the essentialist/constructionist dichotomy brings about the discrediting 
of the entire ecofeminist movement since it is then associated with the natural (a category which is generally berated) as opposed to the cultural.

In the same way as a solely socialist or feminist analysis might be considered reductionist in that it tackles only one side of a question which obviously has different facets, we have to ask ourselves, in light of the current social and environmental crisis, if the essentialist/constructionist dichotomy remains legitimate as an approach to ecofeminism. This question was put forth as early as 1989 by Diana Fuss in her book Essentially Speaking: Feminism, Nature \& Difference, but the importance of Fuss's ideas was swept up by the turmoil of fear that the word "essentialist" created around the ecofeminist movement. Fuss advocated a withdrawal from the opposition between essentialism and constructionism because she considered this to be the root of many negative reactions as regards feminisms and ecofeminisms in the past decades: "[...] it can also be maintained that this same dispute has created the current impasse in feminism, an impasse predicated on the difficulty of theorizing the social in relation to the natural, or the theoretical in relation to the political" (Fuss 1990: 1).

According to her, the problem brought up by this dichotomy did not come from the actual essentialist quality of an idea, but from the suspicion of essentialism, which completely paralyzed the pursuance of the analysis:

Few other words in the vocabulary of contemporary critical theory are so persistently maligned, so little interrogated, and so predictably summoned as a term of infallible critique. The sheer rhetorical power of essentialism as an expression of disapprobation and disparagement was recently dramatized for me in the classroom when one of my most theoretically sophisticated students, with all the weight of recent feminist theory behind her, sought to persuade me that the Marxist-feminist text I had assigned did not deserve our serious consideration. [...] My response to this student's charge might also serve as the keynote to this book: in and of itself, essentialism is neither good nor bad, progressive nor reactionary, beneficial nor dangerous. The question we should be asking is not "is this text essentialist (and therefore "bad')?" but rather, "if this text is essentialist, what motivates its deployment?" How does the sign "essence" circulate in various contemporary critical debates? Where, and how, and why is it invoked? What are its political and textual effects? These, to me, pose the more interesting and ultimately the more difficult questions. (Fuss xi)

In short, if one understands ecofeminist theories as the tacit avowal of a biological link between women and nature, the movement might of course appear as detrimental to both a change in the status of women and an evolution in the abusive exploitation of nature within industrial Western societies. However, rather than turning away from new theories under the pretext that some of its advocates could, maybe, display essentialist ideas, it might be more interesting to ask the question from a critical perspective in order to know if this essentialism could be of interest in the necessary renewal of our world conceptions. If the answer is no, then we would have a solid reason not to show any interest in the ideas expressed in these texts. But, if there exists the slightest possibility that the answer be yes ("yes, even this essentialist-ish texts could be of interest in renewing our world conceptions"), are we not risking losing an important element by rejecting a whole current of thought simply because of a few "free spirits" in its midst? Seeing the hostility with which ecofeminism has been welcomed, at time, it did indeed seem as if the academic world was willing to take the risk of losing important elements within ecofeminist thinking, in short, it appeared as though academe were willing to throw the baby out with the bathwater. 


\section{When literature allows making amends} In 1998, Patrick D. Murphy and Greta Gaard co-edited Ecofeminist Literary Criticism: Theory, Interpretation, Pedagogy, an enriched version of the special issue they had edited on the same subject for the journal ISLE: Interdisciplinary Studies in Literature and Environment in 1996. This convergence of activist and literary theories offered a diversity of analysis which drew from the feminist ecological history in order to multiply the ways in which ecofeminist literary criticism could be put into practice. Contrary to other theoretical works which silenced the problematic "essentialist" side of cultural ecofeminism, both editors addressed the broad variety of standpoints within the movement and referred to these problems that have arisen as regards cultural ecofeminism as early as the Foreword of the book. However, rather than considering that these problems should be dismissed in order to better understand the rest of the movement, the editors focus on the fact that variety is a necessary ingredient within the ecofeminist movement which should not be discarded because of some diverging viewpoints.

The literary criticism that has since developed from ecofeminist social theory had a specific importance for various reasons: first, it offered the possibility of leaving behind the aforementioned fruitless debates concerning essentialism, and, more importantly, it raised those questions which, according to Diana Fuss, might make our critical approaches more comprehensive, and thus, more suitable to a new way of inhabiting the world. Whereas a growing number of scholars seemed to turn away from ecofeminism-or they seemed at least to avoid the use of the term in order not to be brought into disrepute-, this new use of ecofeminist theories allowed a return to favor of the movement as a whole. Although the vast diversity of possible approaches and uses had pushed some to predict the end of ecofeminism, the turn of the $21^{\text {st }}$ century witnessed a use as yet unexplored.

Even if Gaard and Murphy were at the origin of the so-called "ecofeminist literary criticism" and have been the first to use ecofeminism as a new means of practicing critical literary analysis, it is important to note that Annette Kolodny $(1975,1984)$ and Susan Griffin (1978) had both already produced literary analyses that took ecofeminism as a starting point.

It is true that literature offers what we could call a closed realm within which it is possible to put into practice ecofeminist theories in a way that seems less problematic to our critical minds. When applied to literature, the angles of the categories our minds function with are less torn into liminality than when applied to the practical social philosophy of ecofeminism. Given the reduced field of application-be it for ecofeminist literature or literary criticism-, it seems easier to accept these ideas when they apply to a text rather than when they pertain to a global world-view. The subjectivity (the word should not make us tremble) that comes into play (be it in writing or analyzing a text, or even in the mere choice of a text) allows ecofeminist ideas to be accepted in a less problematic manner. Indeed, what is taken into account is one author's perception of the world. As such, it can be considered less controversial since accepting these words as truthful, exact or valuable then becomes a subjective question, a personal one. On the one hand, analyzing a text allows us to simplify the way one approaches the 
ecofeminist movement, and on the other hand, it also allows for a better understanding of the ideas put forth by ecofeminism:

Literature, by its very definition in our society, has been used to make the theoretical practical, to transform complex philosophy into concrete experience through the imagination. Since ecofeminism proposes to be a way of life more than a theory, literature seems a natural medium for disseminating its ideas and practices. By incorporating the tenets of ecofeminism into literature, people can discover avenues for discussion leading to practical application of its theories. But the first step is making people aware of the problems and the interconnectedness of life, of cause and effect, and of the need to take personal responsibility for the consequences of our actions. (Bennett 2012: 10)

\section{Literature as the starting point for a new transdisciplinarity}

theory that tried to hold the socio-critical movement together appeared to be struggling. The disputes that raged inside the ecofeminist movement because of the problem of language and the dichotomies it keeps conveying, led some of its advocates to scatter under various new denominations: material feminisms, queer ecology, feminist environmentalism, global feminist environmental justice, etc. Although their methodological approach may differ slightly from what ecofeminist theory started as, it is important to note that the core ideas remained unchanged. Their main purpose is still a focus on the interrelated nature of oppressive and discriminatory structures as regards social class, gender, sexual orientation, environmental justice, or inter-species relations in order to condemn systems of oppression and categorization which are at the core of today's social and ecological crisis. If there is one field in which ecofeminism continued to exist in spite of the apparent scattering of its original? practitioners, it is within the literary environment that unfolded around it, within which it reinforced itself so as to be taken seriously by academia and academic circles, starting in the United States, partly thanks to the fact that a great number of its writers and advocates are active teachers as well. By avoiding ecofeminism's social theories as a point of entry into the movement, the literary environment around ecofeminism eludes the essentialist controversies which affected the theoretical side:

Rather than simply critiquing or reversing binaries, affective narration creates a foundation for a redefinition of the human; focusing on experiences that involve complex interaction between mind and body, or between human and environment, destroys the illusion of their separation and allows for considerations of human participation in dynamic relationships with non-human nature. (Estok et al. 2013:

11)

As a young scholar working on ecofeminism, I have witnessed an important change within my own research field, namely American and Anglophone studies. My work has gone from being received as something totally alien and potentially dangerous to a new fashionable topic, the next best thing. This newly-found success is confirmed by the fact that ecofeminist texts are entering (albeit slowly) the academic corpus or by exciting new projects such as the new collection "Sorcières" of the Cambourakis publishing house which illustrates how literature can prove helpful in disseminating ideas. A large number of conferences and international symposiums have dealt with subjects pertaining to ecocriticism, feminist ecocriticism and thus, by extension, 
ecofeminism as well-and more are being organized. Ecofeminism can be regarded as a promising transdisciplinary critical tool which continues, whether it be on a literary, social or environmental level, to insist on the plurality of angles and on the liminality of limes, in order for research to be fully representative of the planet's cultural and biological diversity.

\section{BIBLIOGRAPHY}

Adams, Caroll. The Sexual Politics of Meat. New York: Continuum, 1990.

Adams, Caroll, ed. Ecofeminism and the Sacred. New York: Continuum, 1993.

Alaimo, Stacy. Undomesticated Ground: Recasting Nature as Feminist Space. London: Cornell UP, 2000.

Atwoord, Margaret. Oryx and Crake. New York: Anchor Books, 2004.

Bennett, Barbara. Scheherazade's Daughters: The Power of Storytelling in Ecofeminist Change. New York: Peter Lang, 2012.

Brugeron, Pierre-Emmanuel. "Eco-Féminisme : la nature du lien." Implications Philosophiques (2009). http://www.implications-philosophiques.org/societe-2/environnement/eco-feminismela-nature-du-lien/

Carson, Rachel. Silent Spring. New York: Mariner Books, 2002.

Carlassare, Elizabeth. "Essentialism in Ecofeminist Discourse." Ecology. Ed. Merchant, Carolyn. Atlantic Highlands: Humanity Books, 1994. 220-234.

Collard, Andrée, and Joyce Contrucci. The Rape of the World: Man's Violence against Animals and the Earth. London: The Women's Press, 1989.

Cook, Julie. “The Philosophical Colonization of Ecofeminism.” Environmental Ethics 20.3 (1998): 227-246. DOI: 10.5840/enviroethics199820316

Cuomo, Chris. Feminism and Ecological Communities: An Ethic of Flourishing. London: Routledge, 1998.

Daly, Mary. Gyne/Ecology. The Methaethics of Radical Feminism. Boston: Beacon Press, 1990.

Diamond, Irene, and Gloria Orenstein, eds. Reweaving the World: The Emergence of Ecofeminism. San Francisco: Sierra Club Books, 1990.

Dunayer, Joan. Animal Equality: Language and Liberation. Derwood: Ryce, 2001.

Estok Simon C., Greta Gaard, and Serpil Oppermann, eds. International Perspectives in Feminist Ecocriticism. New York: Routledge, 2013.

Evans, Nicholas. The Loop. New York: Random House, 1998.

Fuss Diana. Essentially Speaking: Feminism, Nature \& Difference. London: Routledge, 1990.

Gaard, Greta. "New Directions for Ecofeminism." ISLE: Interdisciplinary Studies in Literature and Environment 17.4 (2010): 643-665. DOI: 10.1093/isle/isq108 
Gaard, Greta. "Ecofeminism Revisited: Rejecting Essentialism and Re-Placing Species in a Material Feminist Environmentalism.” Feminist Formations 23.2 (2011): 26-53. DOI: 10.1353/ff.2011.0017

Gaard, Greta. "Explosion.” Ethics \& the Environment 8.2 (2003): 71-79. DOI: 10.1353/een.2003.0020

Gaard, Greta. "Women, Water, Energy: An Ecofeminist Approach." Organization \& Environment 14.2 (2001): 157-172. DOI: 10.1177/1086026601142002

Gaard, Greta, and Patrick D. Murphy, eds. Ecofeminist Literary Criticism: Theory, Interpretation, Pedagogy. Urbana: U. of Illinois P., 1998.

Gaard, Greta. “Toward a Queer Ecofeminism.” Hypatia 12.1 (1997): 114-137. DOI: 10.1111/j. 1527-2001.1997.tb00174.x

Gaard, Greta. ed. Ecofeminism: Women, Animals, Nature. Philadelphia: Temple UP, 1993.

Gaard, Greta. “Misunderstanding Ecofeminism.” Z Papers 3.1 (1992): 20-24.

Griffin, Susan. Woman and Nature: The Roaring inside Her. London: The Women's Press, 1978.

Haraway, Donna. The Companion Species Manifesto: Dogs, People, and Significant Otherness. Chicago: Prickly Paradigm Press, 2003.

Haraway, Donna. The Haraway Reader. New York: Routledge, 2004.

Haraway, Donna. Modest_Witness@Second_Millennium.FemaleMan@__Meets_OncoMouse ${ }^{\mathrm{TM}}$ : Feminism and Technoscience. New York: Routledge, 1997.

Haraway, Donna. When Species Meet. Minneapolis: Minnesota UP, 2008.

Hawthorne, Susan. Wild Politics: Feminism, Globalisation, and Bio/Diversity. Melbourne: Spinifex Press, 2002.

Hogan, Linda. The Woman who Watches over the World: A Native Memoir. New York: WW Norton \& Company, 2002.

Hogan, Linda Power: a novel. New York: WW Norton \& Company, 1998.

Kheel, Marti. “The Liberation of Nature: a Circular Affair.” Environmental Ethics 7.2 (1985): 134-149. DOI: 10.5840/enviroethics19857223

Kingsolver, Barbara. Flight Behavior. New York: Harper Perennial, 2013.

Kingsolver, Barbara. “Animal Liberation Is a Feminist Issue.” The New Catalyst Quarterly 10 (1989): 8-9.

Kingsolver, Barbara. Nature Ethics: An Ecofeminist Perspective. Lanham: Rowman \& Littlefield, 2008.

King, Ynestra. "Healing the Wounds: Feminism, Ecology and Nature/Culture Dualism." Gender/ Body/Knowledge: Feminist Reconstructions of Being and Knowing. Eds. Bordo Susan \& Alison Jaggar. New Brunswick: Rutgers UP, 1989. 115-141.

Kolodny, Anette. The Lay of the Land: The Land as Experience and History in American Life and Letters. Chapel Hill: North California UP, 1984.

Merchant, Carolyn. The Death of Nature: Women, Ecology and the Scientific Revolution. San Francisco: Harper Collins, 1980.

Merchant, Carolyn, ed. Ecology. Atlantic Highlands, NJ: Humanity Books, 1994.

Mies, Maria. Indian Women and Patriarchy: Conflicts and Dilemmas for Student and Working Women. New Delhi: Concept, 1980. 
Mies, Maria, and Vandana Shiva. Ecofeminism. London: Zed Press, 1993.

Mohanty, Chandra. "Under Western Eyes: Feminist Scholarship and Colonial Discourses." Feminist Review 30 (1988): 61-88. DOI: 10.1057/fr.1988.42

Murphy, Patrick D. Literature, Nature, and Other: Ecofeminist Critiques. New York: SUNY, 1995.

Plant, Judith, ed. Healing the Wounds: The Promise of Ecofeminism. Philadelphia: New Society, 1989.

Plumwood, Val. "Ecofeminism: An Overview and Discussion of Positions and Arguments." Australasian Journal of Philosophy 64 (1986): 120-138. DOI: 10.1080/00048402.1986.9755430

Plumwood, Val. "Feminism and Ecofeminism: Beyond the Dualistic Assumptions of Women, Men and Nature." The Ecologist 22.1 (1992): 8-13.

Plumwood, Val. Feminism and the Mastery of Nature. London: Routledge, 1993.

Quinby, Lee. "Ecofeminism and the Politics of Resistance." Reweaving the World: The Emergence of Ecofeminism. Eds. Diamond, Irene \& Orenstein, Gloria. San Francisco: Sierra Club Books, 1990.

122-127.

Radforth-Ruether, Rosemary. New Woman, New Earth. Sexist Ideologies and Human Liberation. Boston: Beacon Press, 1975.

Radforth-Ruether, Rosemary. Sexism and God-Talk: Toward a Feminist Theology. Boston: Beacon Press, 1983.

Radforth-Ruether, Rosemary. Gaia and God: an Ecofeminist Theology of Earth Healing. San Francisco: Harper Collins, 1992.

Salleh, Ariel. "Deeper than Deep Ecology: The Eco-Feminist Connection." Environmental Ethics 6.1 (1984): 339-345. DOI: 10.5840/enviroethics1984645

Salleh, Ariel. Ecofeminism as Politics: Nature, Marx and the Postmodern. London: Zed Books, 1997.

Salleh, Ariel. "Global Alternatives and the Meta-Industrial Class." New Socialisms: Futures Beyond Globalization. Eds. Albritton, Robert \& Bell, Shannon. New York: Routledge, 2004. 201-211.

Shiva, Vandana. Staying Alive: Women, Ecology and Development. New Jersey: Zed Books, 1988.

Spiegel, Marjorie. The Dreaded Comparison: Human and Animal Slavery. New York: Mirror Books, 1997.

Spretnak, Charlene. The Politics of Women's Spirituality. New York: Anchor Books, 1982.

Spretnak, Charlene. "Toward an Ecofeminist Spirituality" Healing The Wounds: The Promise of Ecofeminism. Ed. Plant, Judith. Philadelphia: New Society, 1989. 127-132.

Stacey, Jackie. “Untangling Feminist Theory." Introducing Women's Studies: Feminist Theory and Practice. Eds. Richardson, Diane \& Robinson, Victoria. New York: Palgrave Macmillan, 1993. 64-72.

Starhawk. The Spiral Dance: A Re-Birth of the Ancient Religion of the Goddess. New York: HarperOne, 1999.

Starhawk. Dreaming the Dark: Magic, Sex and Politics. Boston: Beacon Press, 1982.

Starhawk. "Feminist Earth-Based Spirituality and Ecofeminism." Healing The Wounds: The Promise of Ecofeminism. Ed. Plant, Judith. Philadelphia: New Society, 1989. 174-188.

Sturgeon, Noel. Ecofeminist Natures: Race, Gender, Feminist Theory and Political Action. London: Routledge, 1997. 
Tempest Williams, Terry. Refuge: an Unnatural History of Family and Place. New York: Vintage Books, 1991.

Twine, Richard. “Ecofeminisms in Process.” Ecofem Journal (2001). http://richardtwine.com/ ecofem/ecofem2001.pdf

Warren, Karen. "Feminism and Ecology: Making Connections." Environmental Ethics 9.1 (1987): 3-20. DOI: $10.5840 /$ enviroethics19879113

Warren, Karen. "The Power and Promise of Ecological Feminism." Environmental Ethics 12.2 (1990): 125-146. DOI: 10.5840 /enviroethics199012221

Warren, Karen, ed. Ecological Feminism. London: Routledge, 1994.

Warren, Karen, ed. Ecological Feminist Philosophies. Indianapolis: Indiana UP, 1996.

\section{NOTES}

1. For more information on these writings and on the grassroots beginnings of the ecofeminist movement, see International Perspectives in Feminist Ecocriticism, 1-16 (see reference section infra).

2. Cultural ecofeminism is the spiritual branch of the movement, also sometimes referred to as Goddess Spirituality. The adjective "cultural" refers to "cultural feminism", also known as "differential feminism", which advocates a feminine and masculine fixed biology.

3. The term "speciesism" is usually used to refer to "human supremacy": the idea according to which being humans is enough to have stronger moral rights over other species. "Naturism" has been defined as synonymous of the word "speciesism". Both pertain to a value-hierarchical thought according to which one species has more value than another. A human would thus be more important than a dog, but a dog (given its use and relation with humans) would have more value than an ant, for example. In short, naturism corresponds to thinking that the cultural has more value than the natural, as in the dichotomies nature/culture and body/mind.

4. To name but a few: Marxist, liberal, liberal egalitarian, postmodern, radical, materialist, radical materialist, black, and lesbian feminisms.

5. See for example the works of Brenda Peterson, Linda Hogan, Terry Tempest Williams, Margaret Atwood and Barbara Kingsolver or even Nicholas Evans's popular novels (see reference section infra). For more information on ecofeminist literature, see Scheherazade's Daughters (see reference section infra).

\section{ABSTRACTS}

As an activist and research movement, ecofeminism is concerned with the interrelations between sexism, racism, speciesism and environmental degradation. Thus, from its beginning in the 1970s, the ecofeminist movement has argued that angles and "limes" between disciplines were not always as definite as one might think. This article proposes to draw on the latest evolutions in the field of ecofeminist studies-namely the fact that ecofeminist literary criticism has successfully used literature out of its literary limits as an inter-space between practice and theory -and from my own experience as a young scholar working on ecofeminism, in order to clarify 
the ecofeminist approach to limits and angles on the one hand. It also aims to demonstrate how the problems ecofeminism encountered in successfully dealing with its problematic transdisciplinarity might serve to help further other interdisciplinary research in AngloAmerican studies.

En tant que mouvement activiste militant et universitaire, l'écoféminisme s'intéresse aux corrélations entre sexisme, racisme, spécisme et dégradation environnementale. Depuis ses débuts dans les années 1970, la mouvance écoféministe a mis l'emphase sur le fait que les angles et les lignes séparatrices entre les disciplines n'étaient pas toujours aussi évidents qu'il apparaît. Cet article propose de puiser au sein des dernières évolutions dans le domaine des études écoféministes-notamment le fait que la critique littéraire écoféministe s'est, avec succès, servi de la littérature comme d'un espace tampon entre pratique et théorie-et au sein de ma propre expérience en tant que jeune chercheuse spécialisée en écoféminisme, afin d'illustrer l'approche que l'écoféminisme fait des limites et des angles. Il vise aussi à exposer comment les obstacles dépassés par la mouvance écoféministe en matière d'interdisciplinarité pourraient s'avérer utiles à l'évolution d'autres recherches interdisciplinaires dans les études anglo-américaines.

\section{INDEX}

Mots-clés: écofeminisme, écocritique féministe, transdisciplinarité, sexisme, spécisme, philosophie environnementale

Keywords: ecofeminism, feminist ecocriticism, transdisciplinarity, sexism, speciesism, environmental thinking

\section{AUTHOR}

\section{MARGOT LAUWERS}

Margot Lauwers holds a PhD in American Studies from the English Department of the University of Perpignan Via Domitia. Her thesis dissertation "Amazons of the Pen: the literary manifestations of contemporary ecofeminism" lays forth the way literature has helped fuel the activist side of the ecofeminist movement of the past twenty years. Her research focuses on environmental literature and justice, feminism and ecofeminism and the way literature may help bring about societal changes. Contact: margot.lauwers [at] gmail.com 